our scientific terms. In the expression actinism and radiant heat, the cause has been mixed up with the effect. To be consistent, given one class of bodies the rays falling on it should be called actinic rays; whilst, given another, they should be called heat rays.

In 1840 Dr. F. W. Draper, of New York, clearly pointed out the identity in quality (if I may so call it) of the light, heat, and actinic rays, and that identity, I hold, has been confirmed more than once by recent investigators. I speak, perhaps, somewhat strongly on this point as no one knows better than myself the immeasurable mischief which a wrong definition causes in the progress of a scientific education. Men matured in science can aftord to use any definition since they can carefully guard it by mental reservations as to what they really understand by it; but $I$ hold it as a misfortune of no mean order that definitions, which are not so exact as our present state of knowledge can make them, should be given to the uninitiated whose reasoning powers must at the outset be feeble. A definition containing but half a truth must of necessity lead a student of science to a wrong conclusion at some time or another. If our writers of text-books could but be persuaded to write as they believe in this matter, and as some have written (for instance, Clerk Maxwell), we should have fewer mistakes made in explaining the ordinary phenomena met with in daily life.

I think I have now explained what I meant when the answer was given, "There are no such things as heat rays :" a source of energy may be darkly hot as was the kettle, some of the energy radiating from it was expended in heating bodies round it, but that portion which radiated through the holes perforated in the card and which struck the plate was, at all events, partially expended in converting the silver bromide into the sub-bromide.

In the course of these lectures, which I now finish, it has been my endeavour to show you the principles on which experiment in the infra-red region has been carried out, and also to point out the necessity for further work of no light kind in this part of the spectrum. The preceding lectures will also have shown you that work is required to investigate the visible part of the spectrum, and also in the observation of the various phenomena presenting themselves on the solar surface which must of necessity react upon our earth. It has been ignorantly said that the study of solar physics will be exhausted in ten or tweive years, but from what you have heard my colleagues tell you it will surely last our lifetime. If I live till the exhaustion takes place, my allotted threescore and ten years will, I should say, be greatly overstepped. I prophesy, though it can hardly with decency be called a prophecy, that many generations will pass away before all is known of the exact relationship between solar and tervestrial phenomena. What we do know already is hardly the alphabet of the language in which the sun addresses us; and until that alphabet is mastered the whole story that he would tell us must remain undeciphered.

\section{MORPHOLOGY OF THE TEMNOPLEURIDAE}

$\mathrm{THE}$ following is an abstract of a communication read before the Linnean Society, Dec. 15, 1881 :-The Temnopleuridæe, a sub-family of oligopores, are remarkable for their sutural grooves and depressions at the angles of the plates. The author examined the grooves and depressions or pits in Salmacis sulcata, Agass, and found that these last are continued into the test as flask shaped cavities sometimes continuous at their bases which are close to the inside of the test, but do not perforate. This is the case in the median vertical sutures of the interradium and ambulacrum. Between the interradium and the poriferous plates of the ambulacra are numerous pits in vertical series which are the ends of cylinders closed and of ten curved within. Altogether the undermining is considerable. The grooves over the sutural margins are losses to the thickness of the test. The edges of the contiguous plates are sutured together, by a multitude of knobs and sockets $\frac{1}{300}$ of an inch in diameter visible with a hand lens. In the vertical sutures there is an alternate development of knobs and sockets on each plate corresponding to a similar development on the opposed plates. Between the horizontal plate edges are sutures remarkable in their distinctness and position. The apical edges of the interradial plates have multitudes of sockets and the actinal edges, knobs : whilst the apical edges of the ambulacral plates have knobs and the actinal have sockets. The ambulacra, on their interradial edge bave nothing but knobs and the interradial plates corresponding sockets, so that a great series of knobs and socket "dowelling "prevails. Temnopleurus torematicus, Agass., gave similar results modified by the great development of the grooves and the young form was shown to differ from the adult, and to have rows of knobs and sockets, and barely penetrating pits. The arrangement in Salmacis bicolor and Amblypneustes orum was considered. The pits have an importance for they increase the superficies of the derm and near the peristome, as indicated by Lovén, they contain Spharidia.

The paucity of knowledge respecting the union of the plates of the Echinoidea was noticed and the nature of the suturing of Echinus and Diadema was explained, the first resembling part of that of a young Temnopleurus, but it was without knobs and sockets. The author concluded by separating the Temnopleuridæ into two divisions, those with pits and those with grooves without pits. The last are the oldest in time and resemble young modern forms which subsequently develop pits. He reduced the number of genera considerably.

P. M. Duncan

\section{UNIVERSITY AND EDUCATIONAL} INTELLIGENCE

WE are glad to learn that the number of students who have entered the Chemical Laboratory of Firth College, Sheffield, this session, has been so great, that the present accommodation has been quite insufficient. The Council, therefore, decided at their last meeting to erect working benches for sixteen more students. The University of Edinburgh have recently recog. nised Dr. Carnelly, Professor of Chemistry in Firth College, as a Teacher of Medicine in Sheffield, whose lectures on Chemistry, and course of instruction in Practical Chemistry shall qualify for graduates in Medicine in that University. The lectures on Chemistry and Laboratory Practice at Firth College have also been recognised by the Royal College of Surgeons and the Royal College of Physicians.

\section{SCIENTIFIC SERIALS}

American Fournal of Science, October, 188r.-Cause of the arid climate of the western portion of the United States, by C. E. Dutton.-Embryonic forms of trilobites from the primordial rocks of Troy, N.Y., by S. W. Ford.-Observations of comet $b, 188 \mathrm{I}$, by E. S. Holden.-Thickness of the ice sheet at any latitude, by W. J. McGee.-Notes on earthquakes, by C. G. Rockwood. Marine fauna occupying the outer banks off the southern coast of New England, by A. E. Verrill.- Note on the tail of comet $b \mathbf{I} 88 \mathrm{r}$, by L. Boss.-Geological relations of the limestone belts of Westchester Co. New York, by J. D. Dana.

November, 188r.-Jurassic birds and their allies, by O. C. Marsh. - The remarkable aurora of September 12-13, 1881, by J. M. Schæberle,-The stereoscope and vision by optic divergence, by W. L. Stevens. - The electrical resistance and the coefficient of expansion of incandescent platinum, by E. L. Nichols. -Local subsidence produced by an ice-sheet, by W. J. McGee. -Notes on the Laramie group of Southern New Mexico, by J. J. Stevenson.-Polariscopic observations of comet $c$ r88I, by A. W. Wright. - The relative accuracy of different methods of determining the solar parallax, by W. Harkness. - The nature of Cyathophycus, by C. D. Walcott.

Fournal of the Franklin Institute, December, 188r,-Report of the committee on the precautions to be taken to obviate the dangers that may arise from electric lighting.-Report of committee on fire-escapes and elevators.-Chemical methods for analysing rail steel, by $M$. Troilius.-Notes on the properties of dynamo-electric machines, by $\mathrm{E}$. Thomson.-Blast-furnace hearths and linings, by J. Birkinbine.-Sand-filtration at Berlin, by W. R. Nichols. - Report of committee on Griscom's electric motor.-Weighing the sun by a soap-bubble, by P. E. Chase.

Bulletin de l'Académie Royale des Sciences de Belgique, Nos. 9 and Io.-Apropos of determination of latitude, by M. Folie.On the origin of Devonian limestones of Belgium, by $\mathbf{M}$. Dupont.-Application of accidental images (second note), by $M$. Plateau. - A means of measuring the flexure of telescopes, by M. Rouzean. - On the micaceous substance of veins of Nil St. Vincent, by M. Renard.-Reports, \&c.

Archives des Sciences Physiques et Naturelles, December, 188x. -International Geological Congress of Bologna, September and 
October, I880, by M. Renevier.-Meteorological résums of the year 1880 for Geneva and Great St. Bernard, by M. Plantamour. -Periodical movements of the ground indicated by the airbubble of spirit-levels, by the same.-On the movements of the ground, by Col. von Orff.

Reale Istituto Lombardo di Scienze e Lettere. Rendiconti, vol. xiv., fasc. xvii. - On recent discoveries of Silurian fossils in the province of Udine, by M. E. T. Taramelli.-Synthesis of $\beta$ methylpyridine ( $\beta$ picoline), by G. Zanoni.

\section{SOCIETIES AND ACADEMIES LONDON}

Royal Society, December 15, 1881.- "On the Electromotive Properties of the Leaf of Dioner in the Excited and Un. excited States." By J. Burdon Sanderson, M.D., F.R.S., \&c. (Abstract.)

The paper consists of five parts. Part I. is occupied by the examination of two experimental researches, relating to the subject, which have been published in Germany since the date of the author's first communication to the Royal Society, namely, that of Prof. Munk on Dionæa, and of Dr. Kunkel on electromotive action in the living organs of plants. According to Dr. Munk, the electric properties of the leaf may be explained on the theory that each cylindrical cell of its parenchyma is an electromotor, of which the middle is, in the unexcited state, negative to the ends, and that on excitation the electromotive forces of the cells of the apper layer undergo diminution, those of the lower layer an increase. Hle accounts for the diphasic character of the electrical disturbance which follows mechanical excitation by attributing it to the opposite electromotive reactions of the two layers of cells. According to this theory, each cell resembles in its properties the muscle-cylinder ("Untersuchungen," vol. i. p. 682,1848 ) of du Bois-Keymond, differing from it in so far that its poles are positive instead of being negative to its equatorial zone.

Dr. Kunkel's experiments have for their purpose to show that all the electromotive phenomena of plants may be explained as consequences of the movement of water in the organs at the surfaces of which they manife:t themselves. Neither of these theories is consistent with the author's observations.

Part II. contains a description of the apparatus and methods used in the present investigation.

In Part III, are given the experimental results relating to the electromotive propertics of the leaf in the unexcited state, a subject of which the discussion was deferred in the paper com municated by the author (with Mr. Page) in $1876 .^{1}$ The funda. mental fact relating to the distribution of electrical tension on the surface of the leaf when in the unexcited state is found to be that (whatever may be the previous electrical relation between the two surfaces) the upper surface becomes, after one or two excitations, negative to the under, and remains so for some time. Under the conditions stated, this difference of potential between the two surfaces occurs constantly; the differences of potential which present themselves when other points of the surface of the leaf are compared, may be explained as derived from, or dependent on, it.

Part IV. relates to the immediate electrical results of excitation, i.e. to the electrical phenomena of the excitatory process. In investigating these the author takes, as the point of departure, an experiment which includes and serves to explain those obtained by other methods, and is therefore termed the "fundamental experiment." It consists in measuring the successive differences of potential which present themselves between two opposite points on the upper and on the under surface of one lobe of the leaf, during periods which precede, include, and follow the moment at which the opposite lobe is mechanically or electrically excited. In this experiment it is found that, provided that the conditions are favourable to the vigour of the leaf, the changes in the electrical relations of the two surfaces (called the excitatory variation) occur in the following order :-

Before excitation (particu- Upper surface negative to larly if the leaf has been pre- under. viously excited).

At the moment of excitation.

Sudden negativity of under surface, attaining its maximum in about half a second, the difference amounting to not less than ${ }_{1 \frac{1}{8}}^{1}$ Daniell.

I "On the Mechanical Effects and on the Electrical Disturbance conse quent on Excitation, \&c.," Proceedings", December 14, 1876 .
After excitation.

Rapidly increasing negativity of the upper surface, beginning $1 \cdot 5^{\prime \prime}$, and culminating about 3 "after excitation, and slowly
subsiding.

This subsidence is not complete, for, as has been said, the lasting difference between the two surfaces is augmented-the upper surface becoming more negative after each excitation ("after-effect").

When by a similar method two points are taken for comparison on opposite lobes, the phenomena are nore compli. cated, but admit of being explained as resulting from the inore simple case above stated, in which only a few strata of cells are interposed between the leading off electrodes.

In Part $\mathrm{V}$. the relation of the leaf to different modes of excitation is investigated. As regards electrical excitation the results are as foliows:- If a voltaic current is led across one lobe by non-polarisable electrocles applied to opposite surfaces (the other lobe being led off as in the fundamental experiment) a response (excitatory variation) occurs at the moment that the current is closed, provided that the strength of the current is adequate, and not much more than adequate. No response occurs at breaking the current. When a current of more than adequate strength is used, and its direction is downwards, the response at closing is followed by several others. This effect does not happen when the current is directed upwards. To evoke a response a current must be much stronger if directed upwards than if directed downwards through the same electrodes. Weak currents cease to act when their duration is reduccd to I ${ }^{\prime \prime}$; for stronger ones the limit is shorter. Inadequate currents, if directed downwards, produce negativity of the upper surface, which lasts for several scconds after the current is broken. This effect is limited to the surfaces through which the current is led. Its direction shows it is not dependent on polarisation. By opening inducticn-currents, if their strength does not much exceed the limit of adequacy, a leaf may be excited at intervals for several hours without failure. Weaker currents are more effectual when directed downwards tban when directed upwards. If two inadecjuate induction-currents follow one another at any interval less than $0^{\prime \prime} \cdot 4$ and greater than $0^{\prime \prime} \cdot 02$, they may evoke a response. In this case a response follow's the second excitation. When a leaf is subjected to a series of induction currents at short intervals $\left({ }_{2}^{1} \sigma^{\prime \prime}\right)$ the response occurs after a greater or less number of excitations. If the temperature is gradually diminished the number is increased by each diuninution. All of the above statements relating to excitability refer to plants kept in a moist atmosphere at $32-35^{\circ} \mathrm{C}$.

From the preceding facts and others which are stated in the paper, the author infers ( 1 ) that the difference observed between different parts of the surface of the leaf are the expressions of electromotive forces which have their seat in the living protoplasm of the parenchyma cells. (2) That the second phase of the excitatory variation is probably dependent on the diminution of turgor of the excited cells, and therefore on the migration of liquid; (3) but that no such explanation can possilly be accepted of the phenomena of the first phase, the time relations of which, particularly its sudden accession and rapid propagation, show it to be the analogue of the "negative variation" or "action current" of animal physiology.

Zoological Society, January 3.-Prof. W. H. Flower, F.R.S., president, in the chair.-Mr. W. A. Forbes exhibited and made remarks on the horns of the Prong Buck (Antilucapra americana) lately shed by the specimen living in the Society's Gardens. This was, it is believed, the first instance on record of the same individual having shed its horns in captivity in two consecutive years. - A communication was read from Prof. Owen, C. B., on Dinornis (Part xxiii.), containing a description of Dinornis parvus, a new species of about the size of the Dodo, of which a very complete skeleton (now in the British Museum) had been lately discovered in a cavern in the province of Nelson, New Zealand. - A communication was read from M. L. Taczanowski, C.M.Z.S., containing an account of the birds collected by Mr. Stolzmann during his recent journey in North-Fastern Peru, with descriptions of some new species. $-\mathbf{A}$ communication was read from Mr. Martin Jacoby, containing the descriptions of three new genera and fourteen new species of Phytophagous Coleoptera from various localities.-Mr. Oldfield Thomas read a paper on the African Mungooses (Herpestina), in which he reduced the described species of this group to nineteen, divisible into seven genera. - The Rev. Canon Tristram read the clescrip- 